\title{
Plantemateriale frå jordprøver: uviss alder og ubrukt potensial?
}

\author{
MARIA STURE
}

Sture, M. 2016. Plant materials from soil samples: uncertain age and unused potential? AmS-Varia 58, 5-20. Stavanger, ISSN 0332-6306, ISBN 978-82-7760-167-0

The aim of this paper is to assess the assumptions we make about the age of carbonized and uncarbonized plant materials from soil samples. By questioning the age and origin of plant remains, we investigate an unexploited potential of possible archaeological interpretations. As a case study, carbonized and uncarbonized plant remains from a house that dates to the transition between the Pre-Roman Iron Age and the Roman Iron Age at Hove-Sørbø in Southwestern Norway are investigated. As opposed to the original assumptions based on the preservation conditions at the locality, a total of 1062 uncarbonized seeds of the arable weeds fat-hen (Chenopodium album) and corn spurrey (Spergula arvensis) are shown to be contemporary with the house. This is a unique find in Norway, and it is assumed that the seeds are a by-product of crop processing, most likely residues from fine sieving of cereal grains. The literature discussing macro analysis and interpretation relevant for Norwegian archaeological contexts is scarce. This is partly due to the fact that analysis of macro remains from such contexts is inherently interdisciplinary, and therefore dependent upon the involvement of archaeologists as well as palaeobotanists for further method development and knowledge production.

Maria Sture, Museum of Archaeology, University of Stavanger, 4036 STAVANGER, NORWAY, Phone (+47) 51832600.

Keywords: Uncarbonized plant remains, macro subfossils, macro subfossil methodology, taphonomy, Southwestern Norway, Hove-Sørbø.

\section{Innleiing}

Føremålet med denne artikkelen er å sjå kritisk på dei antakingane me gjer oss om alderen på forkola og uforkola plantemateriale frå jordprøver, og å visa noko av potensialet til det uforkola materialet. Eg vil utdjupa dette ved å presentera eit hus datert til eldre jernalder frå lokaliteten Hove-Sørbø i Sandnes kommune, Rogaland, som ein casestudie (Bjørdal 2014, 2017, in press, Svendsen 2014) (Fig. 1). Huset er eit illustrerande døme på korleis meir kunnskap om materiale frå jordprøver kan endra dei antakingane me gjer oss om eit materiale, og samstundes gjera oss i stand til å stilla nye spørsmål. I den generelle diskusjonen vil eg ta for meg nokre utfordringar knytt til makrofossilanalyse som tverrfagleg metode, og korleis kunnskapsproduksjonen rundt forkola og uforkola plantemateriale har vore i Noreg.

Jordprøver er her definerte som prøver frå kulturpåverka kontekstar, som kan innehalda både forkola og uforkola plantemateriale, i hovudsak frø. Slike prøver vert òg kalla makroprøver eller makrofossilprøver fordi materialet me får ut av dei, har makroskopisk storleik. I

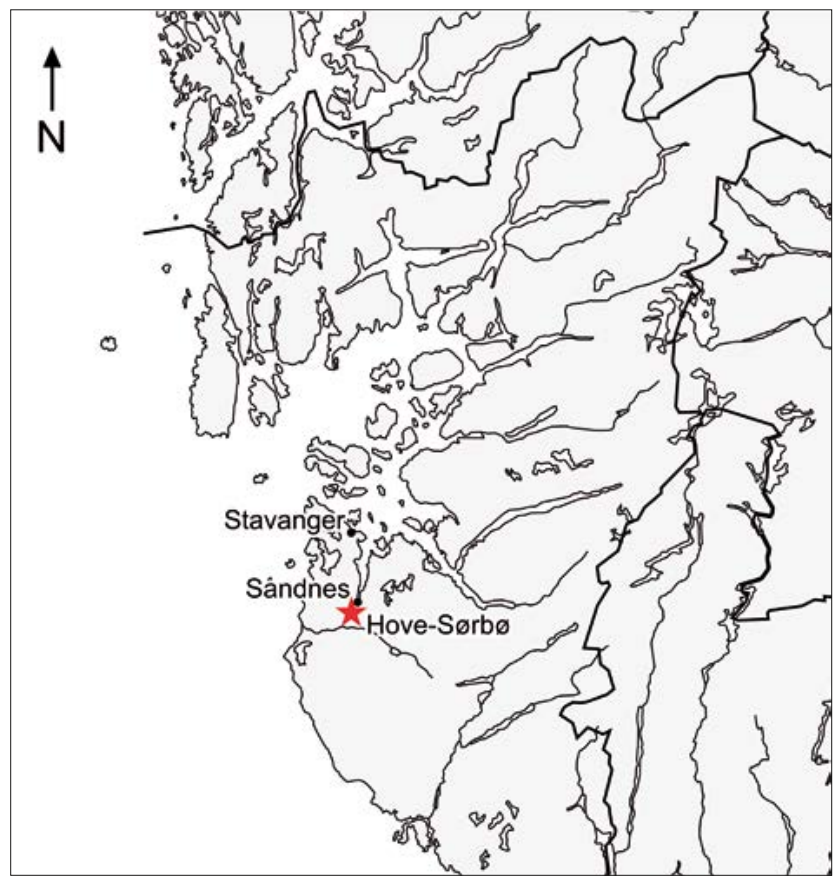

Fig. I. Oversynskart over Rogaland. Lokaliteten Hove-Sørbø er markert med raud stjerne.

Fig. I. Overview map of Rogaland county. The locality Hove-Sørbø is marked with a red star. 
denne artikkelen vil forkola materiale og makrofossil vera synonym, medan makrofossilanalyse refererer til artsbestemming av både forkola og uforkola plantemateriale.

\section{Bakgrunn}

I Noreg er det vanleg å ta utgangspunkt i at uforkola planterestar er moderne kontaminering (sjå t.d. Solem 1999:2, 2004:2-3), med mindre spesielle bevaringstilhøve tilseier noko anna (sjå Svendsen 2014:18-27). Dette er ei fylgje av at bevaringstilhøva for organiske materiale i Noreg generelt er dårlege, samstundes som me manglar empirisk kunnskap om den faktiske alderen på uforkola plantemateriale. Det resulterer i at uforkola plantemateriale sjeldan vert sendt inn til radiokarbondatering, og at kunnskapen me har om dette materialet difor ikkje aukar i takt med talet på jordprøver henta ut frå norske utgravingar.

Likeeins er det vanleg å ta utgangspunkt i at forkola plantemateriale stammar frå brukstida til strukturen dei kjem frå. Forkoling hindrar rask nedbryting, og det forkola materialet er difor statistisk sett eldre enn det uforkola, med større sannsyn for å koma frå ein gjeven, forhistorisk kontekst. Dette treng likevel ikkje vera tilfelle, jamvel om det er vanleg å vurdera eit heilt makrofossilmateriale ut ifrå få, og nokre gonger sprikande, radiokarbondateringar. Eit viktig spørsmål er difor om me bør vera mindre kritiske til det uforkola materialet og meir kritiske til det forkola, ved å revurdera dei generelle antakingane me gjer når me arbeider med desse funnkategoriane.

Dette er eit spørsmål som bør vekkja interesse hjå arkeologar så vel som hjå paleobotanikarar. Det botaniske materialet frå utgravingar er ei verdifull kjelde til kunnskap om fortida, og kan fortelja noko om korleis menneska organiserte liva sine og kulturmiljøet rundt seg. Spesielt frå flateavdekkingar kan det botaniske materialet utgjera ein svært stor del av det tilgjengelege tolkingsgrunnlaget, og det er difor viktig at me har den kunnskapen som trengst for å utnytta det fulle potensialet til materialet.

For å illustrera korleis antakingane våre ikkje alltid stemmer overeins med det føreliggjande materialet, vil eg presentera ein case frå arbeidet med masteravhandlinga mi (Svendsen 2014).

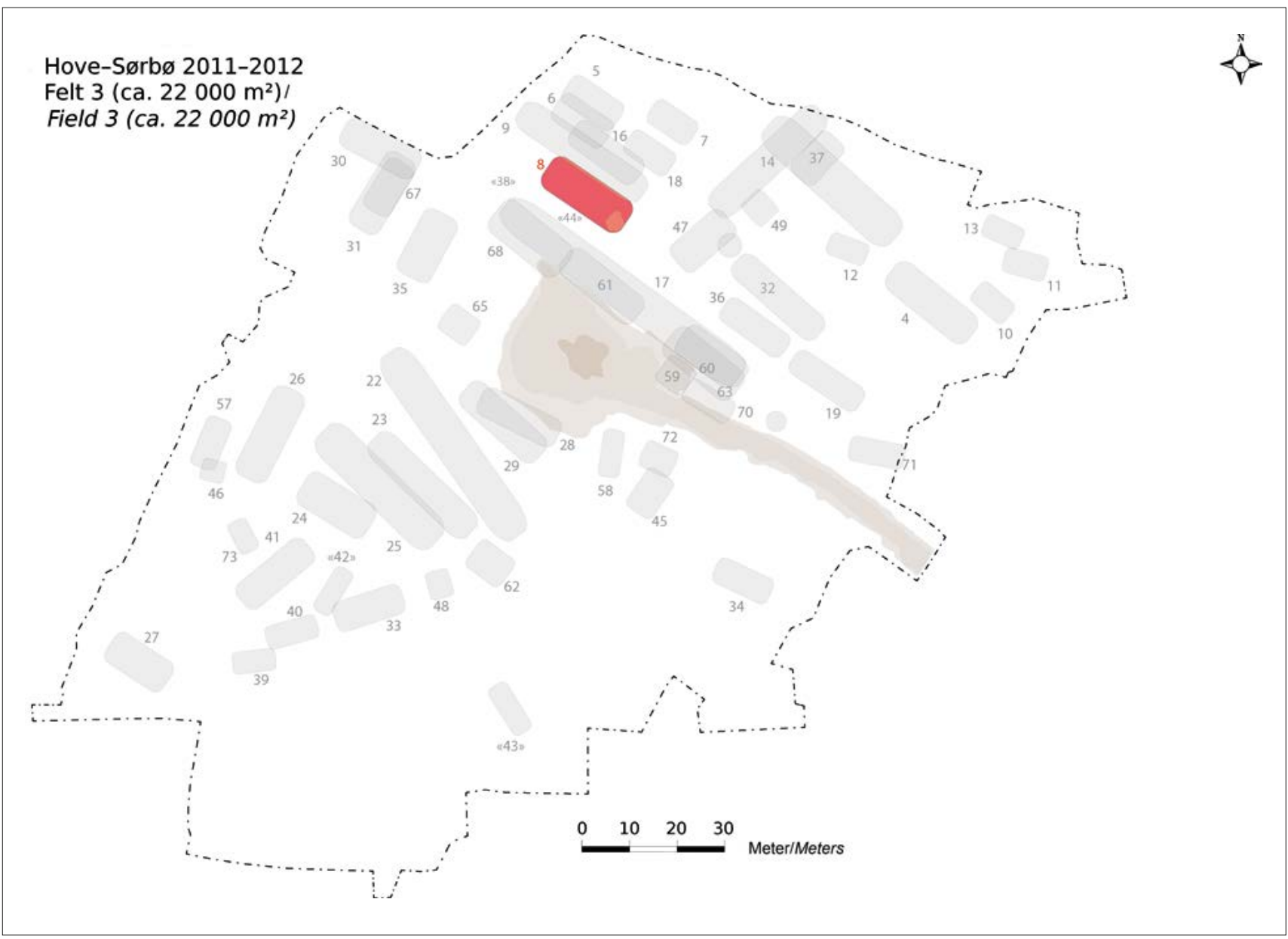

Fig. 2. Felt 3 på Hove-Sørbø med alle utgravne strukturar. Hus 8 er markert i raudt. Illustrasjon av Even Bjørdal. Fig. 2. Field 3 at Hove-Sørbø with all excavated features. House 8 is highlighted. Illustration by Even Bjørdal. 


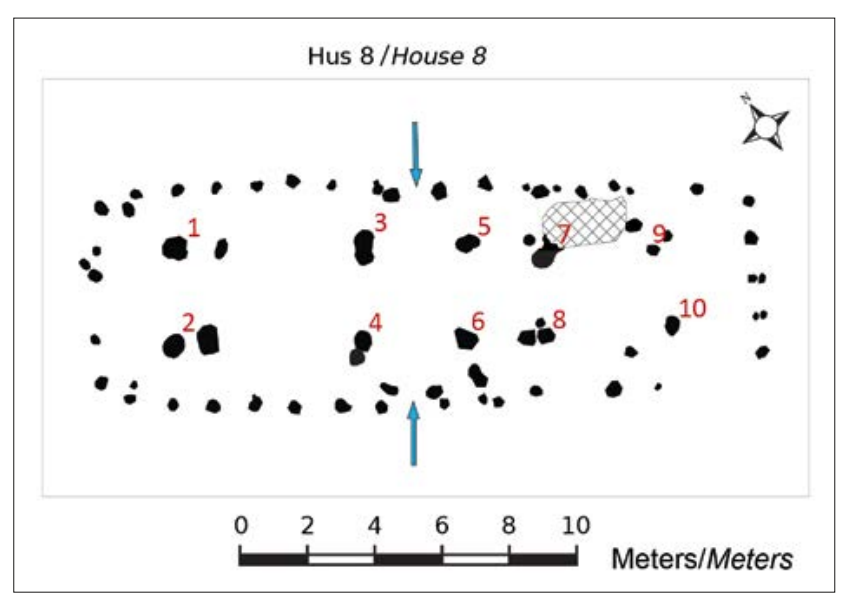

Fig. 3. Planteikning av hus 8 . Dei blå pilene syner inngangspartia. Hòla etter takberande stolpar er nummererte med raude tal. Den skraverte strukturen høyrer til eit yngre hus som har lege over hus 8. Illustrasjon av Even Bjørdal.

Fig. 3. Plan view of house 8 . The blue arrows mark the entrances. The holes from roof supporting posts are marked with red numbers. The shaded structure belongs to a younger house that was placed at the same site as house 8. Illustration by Even Bjørdal.

\section{Case: hus 8 på Hove-Sørbø Jordprøvene frå hus 8}

Lokaliteten Hove-Sørbø ligg om lag 2 kilometer sør for Sandnes sentrum (Fig. 1), under gardsnummer $44 \mathrm{og}$
45, og kan kort skildrast som ei stor flate på eit høgdedrag. Lokaliteten er graven ut av Arkeologisk museum (AM) i feltsesongane 2011-2012. Til saman er over 80 husstrukturar avdekte på lokaliteten, og det er funne spor etter kontinuerleg busetnad frå yngre bronsealder til vikingtid (Bjørdal 2017, in press.). Denne artikkelen baserer seg på plantematerialet frå hus 8 (S 12756) på felt 3 (Fig. 2 og 3). Huset er radiokarbondatert til overgangen førromersk jernalder-romartid (49 f.Kr.-90 e.Kr. og 92 f.Kr.-76 e.Kr.) og er eit treskipa langhus med spor etter fem par takberande stolpar, og midtstilte, motståande dører. Konstruksjonen er typisk både for perioden og landsdelen huset ligg i (Løken 1998:108-111).

I 2012 samla AM inn ti jordprøver frå hus 8, éi prøve frå kvart stolpehòl (sjå Svendsen 2014:102). Stolpehòla har fyrst vorte snitta, og det innsamla materialet er henta frå botnen og oppover i stolpehòla. Den øvste delen av strukturane er ikkje samla inn, men har stått igjen intakt for å unngå moderne kontaminering. Prøvene er floterte i garasjen til AM ved hjelp av ein AmS-flotasjonsmaskin (sjå t.d. Børsheim \& Soltvedt 2002:22-23 for detaljar). Det opphavlege volumet på prøvene har variert frå 2,3 til 4,2 liter. Variasjonen kjem av kor mykje materiale som har vore tilgjengeleg $\mathrm{i}$

\begin{tabular}{|c|c|c|c|c|c|c|c|c|c|c|}
\hline Stolpehòl nr. /Posthole no. & I & 2 & 3 & 4 & 5 & 6 & 7 & 8 & 9 & 10 \\
\hline $\begin{array}{l}\text { Vol. (liter) per prøve/ } \\
\text { Vol. (liters) per sample }\end{array}$ & 4 & 3,5 & 3,5 & 3,1 & 4,2 & 3,8 & 3,3 & 2,8 & 2,3 & 3,8 \\
\hline Alopecurus, Reverumpeslekta/Foxtails & & & & & & 3 & I & & & \\
\hline Avena, Havre/Oat & & & $\mathbf{I}$ & & & & & & I & \\
\hline $\begin{array}{l}\text { Cerealia indeterminate, } \\
\text { Ubestemte korn/Undetermined cereals }\end{array}$ & & & 2 & & I & I & I & & & 2 \\
\hline $\begin{array}{l}\text { Chenopodium, } \\
\text { Ugrasmeldeslekta/Goosefoots }\end{array}$ & & & & & & 2 & & & & \\
\hline Chenopodium album, Meldestokk/Fat-hen & & & & & & & & & I & \\
\hline Hordeum vulgare, Bygg/Barley & I & & 2 & & $\mathbf{I}$ & & & & & \\
\hline $\begin{array}{l}\text { Persicaria lapathifolia, } \\
\text { Kjertelhønsegras/Pale persicaria }\end{array}$ & & & & 1 & & & & & & \\
\hline $\begin{array}{l}\text { Persicaria maculosa, } \\
\text { Vanleg hønsegras/Redshank }\end{array}$ & & & & & & I & & & & \\
\hline Plantago major, Groblad/Greater plantain & & & & & & I & & & & \\
\hline Poaceae, Grasfamilien/Grass family & & $\mathrm{I}$ & & & & & & I & & \\
\hline Rubus idaeus, Bringebær/Raspberry & & & & & & I & & & & \\
\hline Spergula arvensis, Linbendel/Corn spurrey & & I & & & & 3 & & & I & \\
\hline $\begin{array}{l}\text { Stellaria media, } \\
\text { Vassarve/Common chickweed }\end{array}$ & & & & 4 & & 4 & & & & I \\
\hline Indeterminate, Ubestemte/Undetermined & 2 & & & 2 & I & 7 & & I & 2 & 2 \\
\hline Sum frø per liter/Total seeds per liter & I & I & I & 2 & I & 6 & I & I & 2 & I \\
\hline
\end{tabular}

Tabell I. Dei forkola frøa (makrofossila) frå hus 8 på Hove-Sørbø. Korna som vart sende inn til radiokarbondatering (sjå Tabell 3), er markerte i raudt. Frø per liter er runda av til næraste heiltal. Vitskaplege plantenamn og norske populærnamn fylgjer Lid \& Lid (2005), medan engelske populærnamn fylgjer Preston et al. (2002). Table I. The carbonized seeds (macrofossils) from house 8 at Hove-Sørbø. The radiocarbon dated cereal grains (see Table 3) are highlighted. Seeds per liter is rounded to the nearest integer. Scientific plant names and Norwegian common names follow Lid \& Lid (2005), while English common names follow Preston et al. (2002). 
Tabell 2. Dei uforkola frøa frå hus 8 på Hove-Sørbø. Ugrasfrøa som vart sende inn til radiokarbondatering (sjå Tabell 3), er markerte i raudt. Frø per liter er runda av til næraste heiltal. Vitskaplege plantenamn og norske populærnamn fylgjer Lid \& Lid (2005), medan engelske populærnamn fylgjer Preston et al. (2002).

Table 2. The uncarbonized seeds from house 8 at Hove-Sørbø. The radiocarbon dated arable weeds (see Table 3) are highlighted in red. Seeds per liter is rounded to the nearest integer. Scientific plant names and Norwegian common names follow Lid \& Lid (2005), while English common names follow Preston et al. (2002).

\begin{tabular}{|c|c|c|c|c|c|c|c|c|c|c|}
\hline Stolpehòl nr. /Posthole no. & $\mathrm{I}$ & 2 & 3 & 4 & 5 & 6 & 7 & 8 & 9 & 10 \\
\hline Vol. (liter) per prøve/Vol. (liters) per sample & 4 & 3,5 & 3,5 & 3,1 & 4,2 & 3,8 & 3,3 & 2,8 & 2,3 & 3,8 \\
\hline Acer platanoides, Spisslønn/Norway maple & & & & I & & & & & & \\
\hline Artemisia, Malurtslekta/genus Artemisia & & & & & & I & & & & \\
\hline Betula, Bjørkeslekta/Birch & 3 & 5 & I & 16 & & I & 2 & 1 & 6 & \\
\hline $\begin{array}{l}\text { Caryophyllaceae, } \\
\text { Nellikfamilien/Carnation family }\end{array}$ & & & & 1 & & & & & & \\
\hline Chenopodium, Ugrasmeldeslekta/Goosefoots & & & & 1 & & & & & & I \\
\hline Chenopodium album, Meldestokk/Fat-hen & 9 & 49 & 22 & 33 & 11 & 402 & 13 & 5 & 24 & 130 \\
\hline Epilobium, Mjølkeslekta/Willowherbs & & 1 & & 3 & & & & & 1 & 1 \\
\hline Fumaria officinalis, Jordrøyk/Common fumitory & & & I & & & & & & & I \\
\hline Luzula, Frytleslekta/Wood-rush & & & & & & & 1 & & & \\
\hline Montia fontana, Kjeldeurt/Blinks & & & & I & & & & & & \\
\hline Myosotis, Minneblomslekta/Forget-me-not & & 3 & I & 3 & 1 & I & & & 4 & \\
\hline Poa, Rappslekta/Meadow-grass & & & & & & 2 & & & & \\
\hline Poa trivialis, Markrapp/Rough meadow-grass & 1 & & & 10 & 5 & & 11 & & 1 & 31 \\
\hline Poaceae, Grasfamilien/Grass family & & 2 & I & 2 & & & 2 & & & \\
\hline Polygonum aviculare, Tungras/Knotgrass & $\mathrm{I}$ & & & I & & & & & I & 2 \\
\hline Rhinanthus, Engkallslekta/Yellow-rattle & & & I & & & & & & & \\
\hline Sambucus, Hylleslekta/Elder & & & & & & & & & I & \\
\hline Senecio vulgaris, Åkersvineblom/Groundsel & & & & I & & & & & & \\
\hline Silene, Smelleslekta/genus Silene & & & & & & I & & & & \\
\hline Spergula arvensis, Linbendel/Corn spurrey & 5 & 7 & 17 & 101 & 5 & 660 & 62 & & 18 & \\
\hline Stellaria media,Vassarve/Common chickweed & 2 & 3 & 5 & 4 & I & & 8 & & 4 & II \\
\hline Taraxacum, Løvetannslekta/Dandelions & & I & & I & & & 2 & & I & 2 \\
\hline Viola tricolor, Stemorsblom/Wild pansy & & & 2 & & & & & & & \\
\hline Indeterminate, Ubestemte/Undetermined & I & & & I & & & I & 1 & & 9 \\
\hline Sum frø per liter/Total seeds per liter & 6 & 20 & 15 & 58 & 5 & 281 & 31 & 3 & 27 & 49 \\
\hline
\end{tabular}

Tabell 3. Radiokarbondateringane frå hus 8 på Hove-Sørbø. Dei forkola korna har avvikande dateringar, medan dateringane gjorde på trekol og uforkola ugrasfrø samsvarar med den typologiske dateringa på huset. Alle dateringane er utførte av CHRONO Centre ved Queen's University, Belfast. Kalibreringane er gjorde med Calib Rev 7.I (Stuiver \& Reimer 1993).

Table 3. The radiocarbon dates from house 8 at Hove-Sørbø. The carbonized cereal grains show deviating dates, while the dates from charcoal and uncarbonized seeds from arable weeds are consistent with the typology of the house. All dates are from the CHRONO Centre at Queen's University, Belfast. The calibrations are from Calib Rev 7.I (Stuiver \& Reimer 1993).

\begin{tabular}{|c|c|c|c|c|c|}
\hline $\begin{array}{l}\text { Lab. nr./ } \\
\text { Lab. no. }\end{array}$ & Materiale/Material & Art/Species & $\begin{array}{l}\text { Stolpehòl/ } \\
\text { Posthole }\end{array}$ & $\begin{array}{l}\text { Ukal. alder, }{ }^{14} \mathrm{C} \text {-år } \\
\text { BP/Uncal. age, } \\
{ }^{14} \text { C yr BP }\end{array}$ & $\begin{array}{l}\text { Kal. alder BC/AD } \\
(2 \sigma) / C a l . a g e \\
\text { BCIAD }(2 \sigma)\end{array}$ \\
\hline UBA-23347 & Forkola korn/Carbonized cereal & Avena, Havre/Oat & 3 & $97 \pm 28$ & AD 1807-1928 \\
\hline UBA-27406 & Uforkola frø/Uncarbonized seeds & $\begin{array}{l}\text { Spergula arvensis, Linbendel/ } \\
\text { Corn spurrey }\end{array}$ & 6 & $1890 \pm 38$ & AD 5I-228 \\
\hline UBA-27407 & Uforkola frø/Uncarbonized seeds & $\begin{array}{l}\text { Chenopodium album, } \\
\text { Meldestokk/Fat-hen }\end{array}$ & 6 & $1971 \pm 34$ & BC 45-AD 86 \\
\hline UBA-23386 & Trekol/Charcoal & Alnus, Or/Alder & I & $1972 \pm 39$ & BC 49-AD 90 \\
\hline UBA-25064 & Trekol/Charcoal & Lauvtre/Deciduous wood & 8 & $2000 \pm 36$ & BC 92-AD 76 \\
\hline UBA-23346 & Forkola korn/Carbonized cereal & Hordeum, Bygg/Barley & 5 & $3620 \pm 31$ & BC 2040-1893 \\
\hline
\end{tabular}


felt, og storleiken er til dels òg avgrensa av kor mykje tid ein vil investera til analyse av kvar prøve.

Sortering og identifisering av det floterte plantematerialet er utført ved AM (sjå Svendsen 2014:102 for detaljar). Intakte - eller så godt som intakte - frø er talde som eitt individ. Halve frøkapslar er talde som $1 / 2$ individ, medan andre typar fragment av frø er talde som $1 / 3$ individ. Desse verdiane er til slutt lagde saman og runda av til næraste heiltal. I tillegg til relevant litteratur (Bertsch 1941, Katz et al. 1965, Cappers et al. 2006, Nesbitt 2006, Neef et al. 2012) er referansesamlinga til AM og eige innsamla referansemateriale frå lokaliteten Hove-Sørbø i 2012 nytta til bestemming av plantematerialet.

I kvar av prøvene frå hus 8 på Hove-Sørbø har det normalt vore både forkola og uforkola frø, fragment av strå og stilkar, og forkola trevirke. Med unnatak av trekol har materialet i hovudsak vore frø, og størsteparten av desse har vore uforkola. Frå dei ti stolpehòla i hus 8 er det funne 1830 frø. Av desse er 57 forkola (Tabell 1) og 1773 uforkola (Tabell 2). Blant dei forkola frøa er det 13 korn, der fire er bestemte til bygg (Hordeum vulgare), to til havre (Avena), og sju har vore for øydelagde til at nærare identifisering har vore mogleg. Stolpehòl 6 (sjå Fig. 3) skil seg frå dei andre på dei store mengdene uforkola frø frå meldestokk (Chenopodium album) og linbendel (Spergula arvensis).

\section{Dateringane frå hus 8}

Frå hus 8 er det gjort fire radiokarbondateringar innanfor forvaltingsprosjektet, der to vert rekna som kontaminering. Dateringane som samsvarar med typologien til huset, er gjorde på kol av ubestemt lauvtre med datering $2000 \pm 36$ ukal. ${ }^{14} \mathrm{C}$-år BP, og på kol av or (Alnus) med datering $1972 \pm 39$ ukal. ${ }^{14} \mathrm{C}$-år BP. Dei siste to er gjorde på havre (Avena) som er datert til $97 \pm 28$ ukal. ${ }^{14} \mathrm{C}$-år BP, og bygg (Hordeum) som er datert til $3620 \pm 31$ ukal. ${ }^{14} \mathrm{C}$-år BP (Bjørdal 2017, in press.) (Tabell 3). Denne typen dateringar vert ofte lagt til sides, av di det er struktur og ikkje aktivitet som er gjenstand for datering. Dei er likevel verdifulle sidan dei kan tilføra informasjon om graden av kontaminering blant det resterande plantematerialet frå jordprøvene.

Trekol og makrofossil av korn er ofte dei einaste planterestane frå jordprøver som veg nok til at dei kan sendast inn til radiokarbondatering. Individuelle ugrasfrø og vegetative plantedelar er i dei fleste tilfelle så små at datering vert vanskeleg. Frå stolpehòl 6 (sjå Fig. 3) var det mange nok uforkola fragment av meldestokk (Chenopodium album) og linbendel (Spergula arvensis) til at eg i etterkant av arbeidet med masteravhandlinga mi kunne senda inn desse to prøvene til datering. Føremålet med dateringane var å etterprøva om dei uforkola frøa frå Hove-Sørbø var moderne kontaminering. Det har ikkje vore grunn til å tru at noko uforkola plantemateriale ville verta bevart over tid i sur åkerjord utan noka synleg form for forsegling, slik tilhøva rundt hus 8 har vore. Det var difor ei stor overrasking då dateringane av dei uforkola frøa samsvara med dateringane av trekol som truleg stammar frå brukstida til huset. Fragmenta av linbendel (Spergula arvensis), tilsvarande om lag 660 frø, vart daterte til $1890 \pm 38$ ukal. ${ }^{14} \mathrm{C}$-år $\mathrm{BP}$, og fragmenta av meldestokk (Chenopodium album), tilsvarande om lag 402 frø, vart daterte til $1971 \pm 34$ ukal. ${ }^{14} \mathrm{C}$-år BP (Tabell 3).

\section{Diskusjon av materialet \\ Dei forkola frøa i hus 8 (makrofossil)}

Dateringane på plantematerialet frå hus 8 snur dei vanlege antakingane om forkola og uforkola plantemateriale på hovudet. Berre dateringane på trekola har svara til dei forventingane me hadde på førehand. HoveSørbø har ei svært lang historie som bustadslokalitet. Frå utgravinga er det gjort neolittiske dateringar på korn (Bjørdal 2017, in press.), som tyder på samanhengande busetnad frå yngre steinalder til i dag. Det er difor ikkje rart at det har skjedd samanblandingar av jordmassane, og at makrofossila av korn difor ikkje stammar frå brukstida til hus 8 . Desse dateringane er likevel interessante sidan dei dokumenterer jordbruksaktivitet i området over lang tid.

I tilfelle der det har vore samanblanding av eldre og yngre materiale, må me vera merksame på kva det seier om makrofossilmaterialet som heilskap. I hus 8 var ingen av dei to daterte korna frå brukstida til huset. Det burde påverka korleis me ser på dei resterande 11 korna og dei 44 andre forkola frøa frå huset. Ut frå dei to dateringane er det statistisk sett ingen av dei til saman 57 forkola frøa som stammar frå brukstida til huset. Det er likevel ikkje ei sannsynleg slutning, og me må gå ut ifrå at $\mathrm{i}$ alle fall nokre av dei er samtidige med strukturen. Problemet er at me ikkje kan vita kva frø det dreier seg om. Me veit ikkje kva artar, og me veit ikkje kor mange. Det gjer materialet vanskeleg og risikabelt å tolka. Jamvel om me for kvart av korna i prinsippet kan stilla ein hypotese om alderen som det er mogleg å falsifisera, kan me ikkje senda inn alle korna til datering. Dei resterande 44 frøa er alle for små til å kunna daterast i det heile. Me avheng difor av berre to dateringar som sprikar langt i kvar si retning, for å tolka dei forkola frøa som heilskap. 
Denne utfordringa kan vera tydeleg nok når me sit med plantematerialet og dateringane samla. Det er likevel ikkje alltid me får dataa presenterte så tydeleg, og ikkje alle rapportar og publikasjonar tek omsyn til at dateringar og makrofossiltabellar bør presenterast som ein heilskap. Arkeologar og naturvitarar har vorte flinkare til å handtera naturvitskaplege undersøkingar og arkeologiske tolkingar samla, men det er framleis ein tendens til at dateringar som er gjorde på makrofossil, i større grad vert knytte til arkeologiske strukturar enn til makrofossilmaterialet som heilskap. Dette er eit framhald av den vanlege måten å presentera naturvitskaplege undersøkingar på gjennom 1980- og 1990talet, og som Lisbeth Prøsch-Danielsen (2005:17-18) har kalla «appendix-perioden».

Dette tek utgangspunkt i at naturvitskapleg materiale ofte har vorte presentert som eit tillegg til - eller berre delvis integrert i - arkeologiske tolkingar. Når makrofossila ikkje vert presenterte i ein fullstendig kontekst, gjer det lesaren dårlegare rusta til å forholda seg kritisk til materialet. Dette kan forsterka ei framandgjering av dei naturvitskaplege dataa, og i verste fall skapa mistillitt til makrofossilanalyse som metode. Å skaffa seg kompetanse innan dei naturvitskaplege disiplinane $b ø r$ vera eit ansvar som kviler på arkeologane sjølve (sjå Prescott 2012:9), men det er urealistisk å venta at kvar og ein på eigahand skal forstå, analysera og tolka tabellar og data som ikkje vert sett i ein fullstendig kontekst. I tilfellet med hus 8 bør difor ein sentral og tydeleg del av den presenterte makrofossiltolkinga vera at me ikkje kan seia sikkert om nokre av dei forkola frøa var knytte til brukstida til huset.

\section{Dei uforkola frøa i hus 8}

Det er ei større overrasking at det uforkola plantematerialet som vart sendt til datering synte seg å vera samtidig med hus 8. Uforkola frø frå den typen bevaringstilhøve me har på Hove-Sørbø, er unikt i norsk samanheng, og me må difor sjå nærare på korleis dette var mogleg. Under avdekkinga av hus 8 og prøvetakinga frå stolpehòla var det ingen ting som tyda på at materialet har vore forsegla. Likevel har bevaringstilhøva vore så spesielle at dei har stått imot fullstendig nedbryting $\mathrm{i}$ to tusen år. Det tyder på at det må ha skjedd noko utanom det vanlege ved deponering av frøa, og det er gjennom ei slik tafonomisk tolking me òg kan stilla spørsmål som er arkeologisk interessante.

Frø, og spesielt frøskal, er i utgangspunktet meir motstandsdyktige mot nedbryting enn andre plantedelar. Dei skal kunna liggja i jorda og venta på rette forhold med vatn, ljos og varme for å spira. Det er likevel ei grense for kor lenge eit frø kan liggja i jorda om ikkje dei rette forholda oppstår, jamvel om me kjenner til ekstreme tilfelle der frø har halde på spireevna i mange hundre år. Me veit til dømes om frø frå meldestokk (Chenopodium album) og linbendel (Spergula arvensis) som har spira etter så mykje som 1700 år (Ødum 1965:65). Berre det ytste skalet var att av frøa i hus 8 , men dette vil truleg òg vera dei plantedelane som har hatt best føresetnader for å verta bevarte blant det opphavleg deponerte materialet. Bevaring av forhistoriske, uforkola frø er altså mogleg frå flateavdekkingskontekstar som på Hove-Sørbø, dersom frøa i utgangspunktet er motstandsdyktige mot nedbryting.

Me veit at frøa låg samla i eitt stolpehòl, og at dei ikkje hadde vorte bevarte så lenge om ikkje det skjedde noka form for forsegling etter deponeringa. Me veit òg at omrekninga til 402 frø frå meldestokk (Chenopodium album) og 660 frø frå linbendel (Spergula arvensis) tek utgangspunkt i svært fragmenterte frørestar der tre fragment har vorte rekna om til eitt frø. Det er difor sannsynleg at frøa kjem frå ein større konsentrasjon som gjennom to tusen år har gått gjennom mykje kjemisk nedbryting og mekanisk skade.

Radiokarbondateringane syner godt samsvar mellom dei uforkola frøa og trekolet frå huset (Tabell 3). Trekolet gjev dei to eldste dateringane, men her kan eigenalderen til materialet vera ei svak feilkjelde til noko eldre dateringar. Frøa gjev dei to yngste dateringane, men her vil det på motsett vis vera ein viss risiko for at yngre frø frå same art har kontaminert materialet som vart sendt inn til radiokarbondatering. Båe desse feilkjeldene vil i så fall ha drege dateringane marginalt frå kvarandre i tid. Det er likevel lite truleg at kontaminering har påverka dateringane av frøa. Fragmenta i desse prøvene har sett homogent slitne og nedbrotne ut, samstundes som storleiken på prøvene har gjort dei robuste mot ein signifikant påverknad av resultatet.

Me kan stilla spørsmål om kva dei radiokarbondaterte frøa seier om det resterande uforkola plantematerialet. Dette er ein ganske annan situasjon enn med dei forkola frøa sidan utvala av meldestokk (Chenopodium album) og linbendel (Spergula arvensis) i utgangspunktet har representert ein anomali blant dei uforkola frøa. Dateringane seier difor svært lite om resten av utvalet, men dei kan likevel vera til hjelp om me i tillegg ser på plantematerialet. Det vart tydeleg gjennom analysen av dei uforkola frøa at nokre tilsynelatande hadde lege i jorda lenger enn andre. I likskap med dei forkola frøa hadde dei uforkola frøa som vart sende inn til datering, 


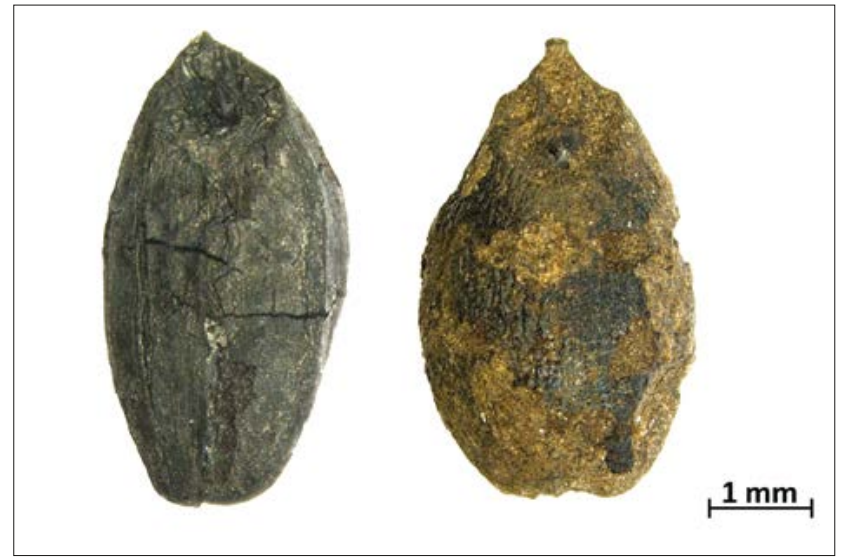

Fig. 4. Venstre: Agnekledd bygg (Hordeum vulgare var. vulgare) som er vaska med flussyre (HF) etter flotering. Her er all silt og leire som var festa til overflata til kornet, vekke. Høgre: Naken bygg (Hordeum vulgare var. nudum) som er flotert, men ikkje vaska med HF. Eit patinaliknande lag av silt og leire sit framleis fast på overflata, og gjev inntrykk av at kornet har lege lenge i jorda. Båe korna kjem frå hus 16 som har lege tett inntil hus 8 (sjå Fig. 2), og er datert til midten av førromersk jernalder. Foto: Maria Sture.

Fig. 4. Left: Hulled barley (Hordeum vulgare var. vulgare) that has been cleaned in hydrofluoric acid (HF) after flotation. Here, all silt and clay that was fixed to the surface of the cereal has been removed. Right: Naked barley (Hordeum vulgare var. nudum) that has been flotated, but not cleaned with HF. An outer layer of silt and clay is still fixed to the surface, giving the impression that the cereal grain has been in the ground for a long time. Both cereal grains come from house 16 that has been situated close to house 8 (see Fig. 2), and dates from the mid-Pre-Roman Iron Age. Photo: Maria Sture. utvikla eit patinaliknande lag av kompakt silt og leire som det ikkje var mogleg å vaska vekk utan bruk av flussyre (HF) (Fig. 4 og 5). Som ein motsetnad til dette har dei fleste andre uforkola frøa fullstendig mangla dette laget, og mange ser svært friske ut, som om dei ikkje skulle ha lege i jorda i det heile. Nokre av desse har òg teke til å spira under flotering og tørking i varmeskap (Fig. 6), og det er lite sannsynleg at frø er bevarte gjennom 2000 år i sur åkerjord i denne tilstanden.

Det kan vera vanskeleg å sjå føre seg korleis så mange friske ugrasfrø skal ha blanda seg inn i prøvene som vart tekne frå snitta og reinska profilar der det øvste jordlaget har stått urørt. Det er likevel mogleg at frø kan ha flytta seg ned gjennom jordmassane gjennom bioturbasjon, frostsprenging, krakeleringar i jordmassane eller med regnvatn (Svendsen 2014:69-70). Forstyrringar i utgravingsområdet rundt hus 8 kan i tillegg ha vore med på å auka kontamineringa. Vinteren 2011-2012 var huset dekt av vegduk, som resulterte i frostsprenging og krakelering av dei øvste jordmassane. Dette laget vart fjerna før utgravingane tok til i 2012, men djupare lag kan framleis ha vorte påverka. Moderne, uforkola frø kan òg ha kome til ved opphoping av regnvatn i dei snitta strukturane før jordprøvene vart tekne ut (Bjørdal 2017, in press.). Det er i tillegg ein større likskap mellom dei artane som veks på Hove-Sørbø i dag og dei

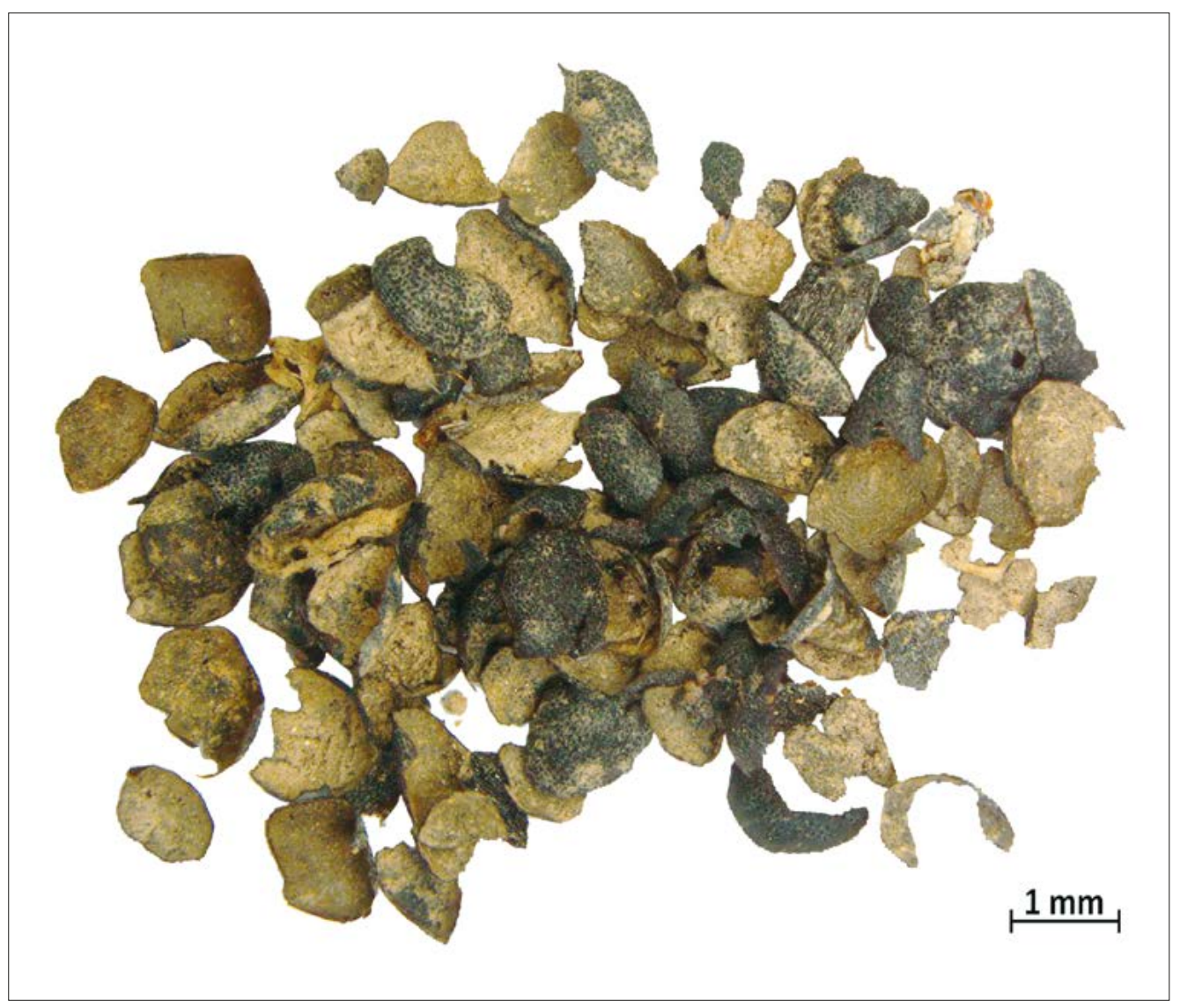

Fig. 5. Nokre av dei 660 frøfragmenta frå linbendel (Spergula arvensis) frå stolpehòl 6 i hus 8 . Me ser tydeleg eit ljosbrunt, patinaliknande lag av silt og leire på frøskala. Foto: Maria Sture.

Fig. 5. Some of the 660 seed fragments of corn spurrey (Spergula arvensis) from posthole 6 in house 8 . We can clearly see a light brown outer layer of silt and clay on the seed coats. Photo: Maria Sture. 
Fig. 6. Frø frå meldestokk (Chenopodium album) som har spira under flotering og tørking av jordprøva. Fire av frøa på biletet har framleis intakt pericarp rundt frøskalet. Frøa er frå stolpehòl $10 \mathrm{i}$ hus 8. Foto: Maria Sture. Fig. 6. Seeds from fat-hen (Chenopodium album) that have sprouted during flotation and drying of the soil sample. Four of the seeds in the picture still have an intact pericarp around the seed coat. The seeds originate from posthole 10 in house 8. Photo: Maria Sture.

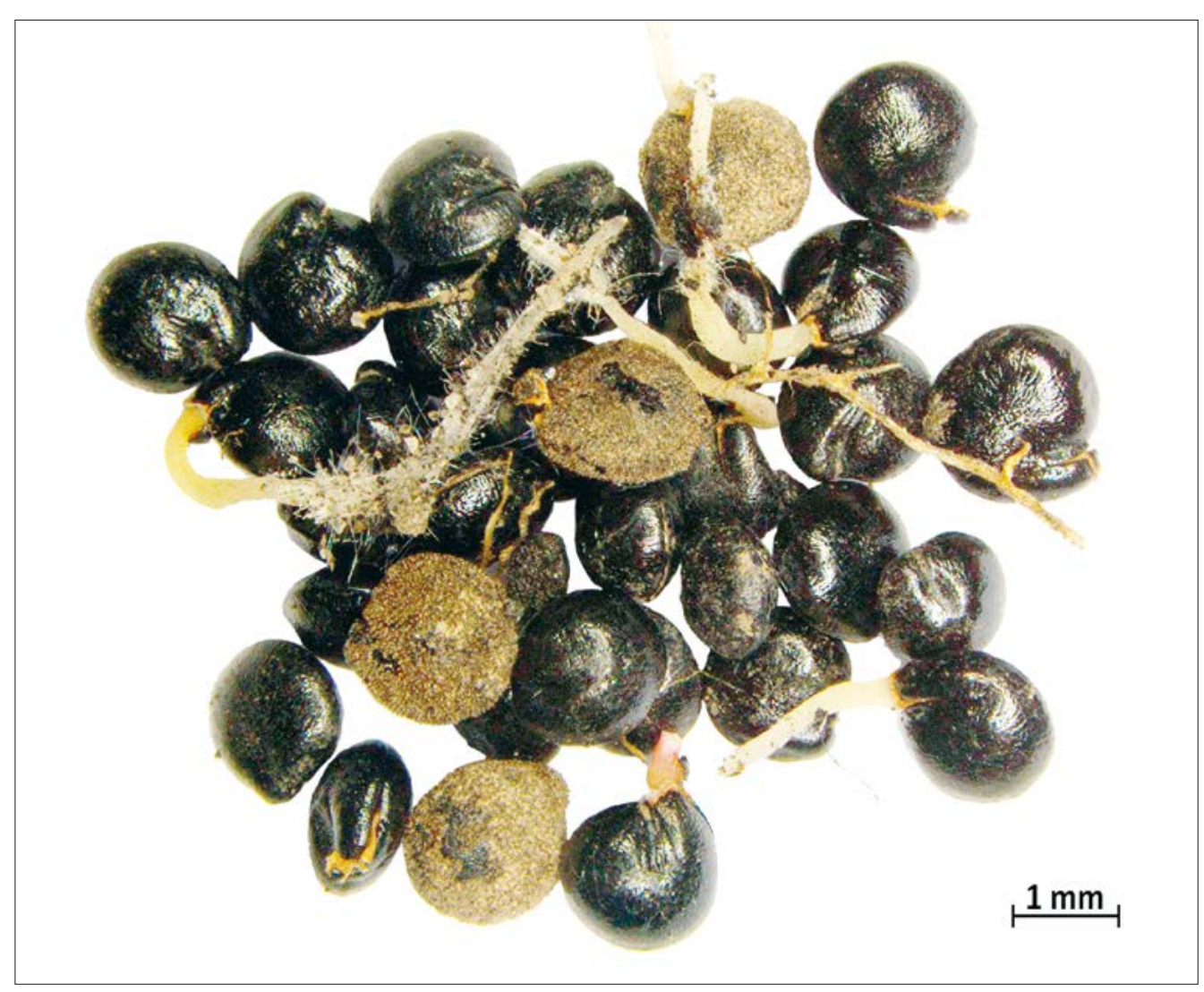

uforkola frøa, enn det er mellom dei forkola frøa og den moderne floraen (Svendsen 2014:54-56, 68-69). Dette peiker òg i retning av at dei uforkola frøa i stor grad representerer moderne kontaminering i jordprøvene, og at dei daterte frøa er eit unnatak.

\section{Tolking av dei forhistoriske, uforkola frøa}

Det er ei mogleg tolking at dei store mengdene meldestokk (Chenopodium album) og linbendel (Spergula arvensis) kjem frå slutten av brukstida til hus 8 , som mest sannsynleg var i tidleg romartid. På denne tida har det vore fleire samtidige hus i tett nærleik til hus 8 (Bjørdal 2014, Bjørdal 2017, in press.), og med stor aktivitet $\mathrm{i}$ området er det lite sannsynleg at huset har vorte ståande og rotna (sjå Svendsen 2014:67-68). Om dei takberande stolpane vart tekne opp av stolpehòla, vil det ha gjort ein forseglingskontekst mogleg for det plantematerialet som allereie fanst i jordmassane rundt stolpehòla. Ei større mengd ugrasfrø kan ha hamna i det tomme stolpehòlet, og hòlet kan relativt raskt ha vorte heilt eller delvis fylt med jordmassar og leire gjennom intensjonell gjenfylling eller erosjon.

Meldestokk (Chenopodium album) og linbendel (Spergula avensis) er vanlege eittårige planter som veks som ugras i åker og på vegkantar og som trivst i høvesvis næringsrik og sur, næringsfattig jord (Behre 1981:236, Lid \& Lid 2005, Grabowski 2012:481). Det vil ha vore rik tilgang på plantene som åkerugras i områda rundt Hove-Sørbø for 2000 år sidan, og båe artane kan ha vore hausta inn som menneskemat eller dyrefôr (Fægri 1970:147, Behre 1981:225, Hillman 1981:156-158, Robinson et al. 2009:118-119). Me kjenner til store konsentrasjonar av frø frå båe artane i eldre jernalder-kontekstar på Jylland (Helbæk 1951a, Henriksen \& Robinson 1996, Viklund 1998:75-77, Hardt 2003:46-47), ikkje minst frå mageinnhaldet til myrlik (Brandt 1951:343, 347, Helbæk 1951b:322-323, 1959:106-107, Harild et al. 2007:172). Frøa frå hus 8 kan likevel ikkje måla seg med desse funna. Til saman 1062 frø er eit stort tal, men når me veit at eitt frø frå meldestokk (Chenopodium album) i snitt veg 1,2 mg, og eitt frø frå linbendel (Spergula arvensis) i snitt veg 0,5 mg (Korsmo et al. 1981:124-125, 132-133), får me at den opphavlege vekta på frøa berre var 0,81 gram. Til samanlikning er dei ulike funna frå Jylland anten over ein liter i volum, eller dei veg fleire hundre gram. Det bør difor finnast ei alternativ tolking til kvifor akkurat desse frøa frå stolpehòl 6 er så talrike.

Sannsynlegvis er dei bevarte frøa berre ein liten fraksjon av ugrasfrøa som ein gong fanst i hus 8 . Både meldestokk (Chenopodium album) og linbendel (Spergula arvensis) har harde frøskal. Det aukar sjansen for at dei vert bevarte over tid, og gjev dei betre sjanse for bevaring enn frø med tynt skal. Det er difor mogleg 
at frøa representerer eit mykje større og annleis utval av botanisk materiale, og at dei berre er den siste resten som er att frå dette utvalet. Frøa kan ha fylgt med innhausta korn frå åkeren og vera eit biprodukt av kornreinsking. Denne tolkinga forklarer kvifor mengda av frø er for stor til at det kan avskrivast som eit tilfelle, men òg for liten til at det kan tolkast som intensjonell innhausting. Korn har tynne frøskal og næringsrike kjernar, og berre ved svært spesielle høve vert desse bevarte over lengre tid i uforkola tilstand (Hillman 1981:123).

Noka form for arbeid med korn i huset kan me likevel rekna med. I stolpehòl 4, på den andre sida av inngangspartiet der ugrasfrøa kjem frå (sjå Fig. 3), er det funne tre forkola rachissegment, der det har vore mogleg å bestemma det eine til naken bygg (Hordeum vulgare var. nudum). Det er rachissegment som utgjer akset kornet er festa til, og delar av desse segmenta kan fylgja med i fleire trinn av kornreinskingsprosessen før dei endeleg vert så godt som fullstendig sorterte ut (Hillman 1981:132-135). Sidan rachissegmenta ikkje er daterte, og dei i tillegg er forkola, er det uvisst om dei stammar frå den same reinskingsaktiviteten. Det er likevel påfallande at funnet av desse òg er gjort samla i nærleiken av inngangspartiet, og det kan indikera at det $\mathrm{i}$ alle fall har vore éi hending med reinsking av naken bygg (Hordeum vulgare var. nudum) i huset.

Det at ugrasfrøa er funne i stolpehòl 6, som ligg nær inngangen til huset, peikar òg i retning av at frøa kjem frå ein kornreinskingsaktivitet. Det har vore mogleg å nytta seg av trekken som oppstår mellom to motståande dører, til å skilja lettare og tyngre fraksjonar frå kvarandre (Viklund 1998:60, 66-68), slik at området rundt inngangspartiet ville ha vore ein veleigna plass for reinskingsaktivitetar. Denne sida av huset er i tillegg vendt mot sørvest som vil ha gjeve mest solinnstråling og varme til aktivitetane som gjekk føre seg der. Både meldestokk (Chenopodium album) og linbendel (Spergula arvensis) er lette frø, men dei er samstundes runde og kompakte. Det er difor meir truleg at dei er sorterte ut ved finsiling av kornet (sjå Hillman 1981:134-135, Renfrew \& Bahn 1991:235, Viklund 1998:33), som òg kan ha gått føre seg ved inngangspartiet. Ved finsiling vil dei fleste ugrasfrøa, saman med svært små korn, rachissegment og agnfragment, gå gjennom sila, medan mesteparten av korna og dei større ugrasfrøa vert att i sila. Dette svarar til Hillmans (1981:135) trinn 7 i prosesseringssekvensen av nakne kornsortar.

Hillman (1984:19-30) har laga eit klassifikasjonssystem for ugrasfrø frå arkeologiske kontekstar. Her samsvarar klassifiseringa av meldestokk (Chenopodium album) og linbendel (Spergula arvensis) med tolkinga over. Ifylgje Hillman er dei åkerugras som vert introduserte i eit aktivitetsområde gjennom hausting av korn og som vert sorterte ut ved finsiling. I tillegg vil gjennomsnittshøgda til plantane som frøa kjem frå, tilseia at kornet er hausta inn ved å kutta stråa eit godt stykke nedanføre aksa (Hillman 1984:20, 27).

Me kan ikkje vita nøyaktig kvifor eller korleis akkurat desse frøa har hamna i stolpehòlet, men det verkar sannsynleg at dei er den siste resten av eit større utval frø og anna plantemateriale frå reinsking av korn, som no har rotna vekk. Det verkar òg sannsynleg at det har skjedd ei spesiell hending raskt etter deponering som heilt eller delvis har forsegla frøa i stolpehòlet. Eit mogleg scenario er at det har skjedd mot slutten av brukstida, kanskje i prosessen med tømming og dekonstruksjon av huset. Dekonstruksjon kan innehalda ulike element som brenning, rydding eller graving, og det treng ikkje å ha vore ein utelukkande funksjonalistisk prosess (sjå t.d. Amundsen \& Fredriksen 2014:91-96). I tilfellet med hus 8 ser det derimot ut til å ha gått føre seg ein dekonstruksjon som me i dag kan sjå på som både praktisk og rasjonell.

Med bakgrunn i det totale innhaldet av trekol og makrofossil i stolpehòla har huset truleg ikkje brunne (Svendsen 2014:67-68). Det ville vore lite sannsynleg å finna så mykje uforkola plantemateriale dersom brukstida til huset hadde enda i ein brann. Funn av større mengder uforkola leire under utgravingane stør òg denne tolkinga (Bjørdal 2017, in press.). Stolpane kan ha vore tekne opp til gjenbruk, og stolpehòla har truleg vorte fylte att raskt. Denne framgangsmåten gjev god meining i eit aktivitets- og busetnadsområde der ein brann lett kunne spreia seg, trevirke vil ha vore ettertrakta, og tomme stolpehòl vil ha vore i vegen for ulike aktivitetar. Frøa kan difor tolkast som del av eit intensjonelt eller tilfeldig fyll i eit ope stolpehòl.

\section{Generell diskusjon Den tverrfaglege utfordringa}

Paleobotanikken er ein av dei viktigaste støttespelarane til norsk arkeologi, og det er avgjerande at arkeologar sjølve tek ansvar for å tileigna seg eit minimum av kunnskap om dei paleobotaniske metodane så vel som andre naturvitskaplege metodar av relevans (Prescott 2012:9). Som arkeolog skal det i dag godt gjerast å koma utanom det viktige bidraget botaniske data er for heilskaplege arkeologiske tolkingar av både lokalitetar og periodar. Naturvitskaplege metodar og ordskifte kan framstå som utilgjengelege og vert mellom anna difor sjeldan objekt for utstrekt merksemd frå arkeologar. 
Desse ordskifta er likevel relevante for arkeologar så vel som for paleobotanikarar. Mangelen på eit tverrfagleg samarbeid vil vera eit tap både for arkeologi som disiplin og for paleobotanikk som metodar, om arkeologane ikkje er i stand til å involvera seg på eit tilstrekkeleg høgt fagleg nivå. Det er samstundes viktig å understreka at det ikkje her er snakk om å ha inngåande kjennskap til dei naturvitskaplege metodane. Det er derimot viktig å ha den tilstrekkelege grunnkunnskapen til å forstå kva som i ulike kontekstar er gode spørsmål og problemstillingar knytt til botanisk materiale.

Jamvel om hovudansvaret for å setja seg inn i naturvitskapleg metode ligg hjå arkeologane, har naturvitarane sjølve høve til å leggja til rette for dette. Det finst fleire tilgjengelege bøker om miljøarkeologi som er grundige i gjennomgangen av paleobotanikk (t.d. Dincauze 2000, O'Connor \& Evans 2005), men slike verk er ofte tilpassa eit breitt, internasjonalt publikum, og vert gjerne for generelle i tematikken, eller for spesielle i døma. Mangelen på ein openberr relevans for norske kontekstar gjer at kunnskapen igjen vert vanskeleg tilgjengeleg. Innan palynologien er det publisert fleire gode bøker og artiklar, inkludert artiklar som er spesielt relevante for Noreg, som forklarer prinsipp og problem for pollenuttak og pollenanalyse (sjå t.d. Behre 1981, Fægri \& Iversen 1989, Davis 2000, Hjelle \& Sugita 2012). Tilsvarande tekstar om makrofossilanalyse har ikkje vore like lett tilgjengelege, men fleire har kome til dei to siste tiåra (t.d. Ranheden 1996, Engelmark 1997, Engelmark et al. 1997, Viklund 1998, Bakkevig et al. 2002), i hovudsak frå eit svensk metodeordskifte.

Ei forklaring på skilnaden mellom ordskifta innan dei to fagfelta kan vera at det frå starten av har vore fleire metodekritiske spørsmål knytt til pollenanalyse (sjå t.d. Fægri \& Iversen 1989, Davis 2000:1-2, Dincauze 2000:343) enn til makrofossilanalyse. Ei anna forklaring kan vera at arbeid med makrofossil ofte, men ikkje alltid, er meir direkte knytt til arkeologiske lokalitetar enn kva pollenanalyse er, i alle fall i kontekstar der me forstår spreiinga av makrofossil som ei fylgje av menneskeleg aktivitet. Det vil i praksis seia at metodeutvikling og metodekritikk av pollenanalyse vert utvikla av ein større fagkrins som er samansett av både reint naturvitskaplege og tverrfaglege paleobotanikarar. Det er mi oppfatning at tilsvarande fagmiljø for makrofossilanalyse har mangla i Noreg. Fagkrinsen som jobbar med metodeutvikling og metodekritikk, er mindre, og i større grad samansett av arkeologar og paleobotanikarar som arbeider tverrfagleg. Dette treng ikkje vera eit vanskeleg utgangspunkt for metodeutvikling - det kan tvert imot vera positivt at fagfeltet per definisjon er tverrfagleg. Samstundes fordrar det òg interesse og prioritering av økonomiske midlar til naturvitskapleg metodeutvikling og metodekritikk frå arkeologisk hald, og her møter me ei utfordring.

Makrofossilanalyse har aldri vore ei ferdig utvikla pakke til bruk i arkeologiske kontekstar, men har utvikla seg ettersom den empiriske kunnskapen om plantemateriale frå desse kontekstane har auka. Av same grunn kan heller ikkje botanikarar aleine ta ansvar for den vidare kunnskapsproduksjonen. I Noreg er det vanleg for arkeologar å forholda seg til at mykje av føremålet med å samla inn jordprøver er å skaffa til vegar plantemateriale som kan datera strukturen dei stammar frå. Når dette dei siste tiåra har vorte ein vanleg framgangsmåte og metode, har det ført til ei instrumentalisering av makrofossilanalyse som metode, og ein statisk måte å forholda seg til makrofossilanalyse på. Det er svært forståeleg at datering av strukturar får høg prioritet, og ofte er makrofossila det einaste materialet me har tilgjengeleg til radiokarbondatering. Det er likevel ingen grunn til at me skal seia oss nøgde med metodeutviklinga og den kunnskapen me kan få ut av prøvene i dag. Mellom anna syner dømet frå hus 8 på Hove-Sørbø at me har grunn til å revurdera korleis me tolkar førhistorisk plantemateriale.

Dersom haldningane våre overfor ein metode ikkje endrar seg over tid, og me i liten grad ser ny kunnskapsutvikling, vil dette verka sjølvforsterkande. Resultatet vert ein metode som ikkje får utvikla seg vidare, og at terskelen for å ta tak i metodiske spørsmål og tolkingsspørsmål vert høgare. Når me allereie gjer god bruk av jordprøvene som dateringsgrunnlag, kan det vera vanskeleg å sjå nytta av vidare metodeutvikling. Dette har dels årsak i dei økonomiske rammene forvaltingsarkeologien må forholda seg til, og dels i at det så langt er få som har hatt andre midlar eller høve til å ta tak i forskingsspørsmål knytt til forkola og uforkola planterestar. Om me igjen ser til palynologien og pollenanalysar, finn me eit stort ordskifte om metode og tolking som stør seg på eit breiare kvartærbotanisk fagmiljø (t.d. Prentice 1985, Sugita 1993, 1994, Jackson \& Lyford 1999, Davis 2000, Seppä \& Bennett 2003, Hjelle \& Sugita 2012).

\section{Tafonomi}

Tafonomi er dei menneskelege, biotiske og abiotiske prosessane som har etterlate det plantematerialet me finn i dag. Den tafonomiske prosessen held fram gjennom produksjon, deponering, nedbryting og eventuell vidare bevaring og stoppar ikkje før alle fysiske spor 
etter det opphavlege materialet er vekke (Dincauze 2000:28, O'Connor \& Evans 2005:69-70). Interessa for tafonomi kom frå USA med prosessuell arkeologi på 1960-talet (Wilkinson \& Stevens 2003:35), men det er framleis eit felt me har for lite kunnskap om (Viklund 1998:16). Tafonomisk kunnskap og forståing er avgjerande for korleis me tolkar eit botanisk materiale: «From a purely practical standpoint, an understanding of the taphonomy of a deposit or material is essential if we are to know what that sample represents in terms of time and space, and thus the constraints and possibilities of its interpretation. Interpretation with inadequate understanding of taphonomy becomes dangerously close to guesswork» (O'Connor \& Evans 2005:70).

Me kan altså ikkje utan vidare tolka eit botanisk materiale utan fyrst å ha nokon grad av kunnskap om paleoøkologi, nedbrytingsprosessar og kvifor og korleis materialet har flytta seg gjennom tid og rom frå ein forhistorisk kontekst. Tilstanden me finn materialet i, er svært relevant for ei arkeologisk tolking, og me treng tafonomisk kunnskap for å svara på spørsmålet om kva materialet me ser på, eigentleg representerer. Kva slags heilskap har det vore del av (sjå O'Connor \& Evans 2005:194), og kva prosessar har ført til at det vart deponert og bevart? Denne kunnskapsproduksjonen er utfordrande. Dei tafonomiske prosessane vil aldri vera dei same i ulike kontekstar og på ulike lokalitetar. Me er difor avhengige av eit stort empirisk grunnlag for å koma i nærleiken av å kunna gjera generelle antakingar som kan overførast til andre kontekstar og lokalitetar.

\section{Kunnskapsstatus for uforkola plantemateriale}

I Noreg er bevaringstilhøva generelt dårlege for arkeobotanisk materiale. Særleg i kystområda gjer sur jord og fuktig klima at organisk materiale som lêr, bein, trevirke og tekstilar ofte vert brote heilt eller delvis ned over relativt kort tid (Bakkevig et al. 2002:25). Uforkola planterestar kan likevel verta bevarte over lang tid dersom dei vert deponerte under stabile tilhøve (Viklund 1998:29). Slike tilhøve føreset i dei fleste tilfelle nokon grad av forsegling, slik at ikkje oksygen og mikroorganismar klarer å bryta ned materialet. Det er truleg dette som er tilfellet med dei uforkola ugrasfrøa frå hus 8 på Hove-Sørbø, men det er ikkje vanleg å rekna stolpehòl som typiske forseglingskontekstar. I land med varmt og tørt klima kan plantemateriale lett verta bevart i tørka tilstand. Sidan klimaet i Noreg ikkje tillèt denne typen bevaring, er det berre i spesielle tilfelle me finn forhistorisk, uforkola materiale. Desse tilfella lèt seg vanskeleg generalisera, og me må difor ta utgangspunkt $\mathrm{i}$ at ingen kontekstar er like når me vurderer alderen på materialet.

Me kjenner til forhistorisk, uforkola plantemateriale frå tre ulike konteksttypar i Noreg. Dette er tilfelle der plantematerialet er frysetørra, nedsøkkt i vatn, eller forsegla av jord eller sand. Plantemateriale kan verta særskilt godt bevart over tid om det vert frysetørra. Deponeringa må då ha skjedd i område med tilnærma permafrost, som delar av nordområda, høgfjella og i brear (sjå t.d. Nesje et al. 2012). Plantemateriale som er konstant nedsøkkt i vatn, kan òg verta godt bevart (Hillman 1981:123, 1984:13, Zohary \& Hopf 2000:4). Dei deponeringane me kjenner til, kjem gjerne frå marine sediment, tjern, myrer og brunnar. Frå E6-prosjektet i Østfold kjenner me til dømes eit tilfelle der forhistorisk, uforkola plantemateriale har vorte bevart til i dag. Det har lege i sediment i brunnen på lokalitet 11 på Søndre Bjørnstad (Sandvik 2008:76), der vatnet har skapt eit oksygenfattig miljø, og nedbrytarorganismar har hatt vanskeleg for å koma til.

Bevaring kan òg skje i kontekstar der plantematerialet vert forsegla raskt etter deponering. Frå Osebergfunnet (Holmboe 1905, 1917) var store mengder uforkola plantemateriale bevart, sidan tjukke lag med torv og leire hadde gjort haugen tilnærma oksygentett. Flygesand skapar tilsvarande oksygenfattige miljø. Denne typen forsegling er mellom anna kjend frå Grønland der ein vikinggard har lege dekt av flygesand sidan busetnaden vart forlaten (Hebsgaard et al. 2009). Me kjenner òg til uforkola plantemateriale frå eit jernalderåkerlag på Sola i Rogaland. Åkeren har vore forsegla av flygesand sidan slutten av bruksfasen, og materialet har difor vorte bevart til i dag (Prøsch-Danielsen 1993, Eilertsen 2011). Det vil likevel vera stor variasjon i kor godt eit materiale vert bevart, og kor representativt det er etter ei gjeven tid i forseglingskontekstar sidan det er større sjanse for at oksygen og mikroorganismar kjem til i små mengder enn om materialet er konstant frose eller nedsøkkt i vatn. Innhaldet i stolpehòl 6 frå hus 8 på Hove-Sørbø er truleg resultatet av ei berre delvis forsegling.

Det er oftast i samband med flateavdekking og jordprøver frå stolpehòl me tradisjonelt har gått ut ifrå at det uforkola plantematerialet er yngre enn det forkola (Solem 1999:2, Solem 2004:2-3). Det er difor òg her me må vera mest observante når me gjer tafonomiske antakingar om plantematerialet. Det er ikkje uvanleg å finna større mengder uforkola planterestar, i hovudsak ugrasfrø, frå stolpehòl eller liknande strukturar. Me har då høve til å stilla to spørsmål: 1 . Dersom dei er 
forhistoriske, korleis vart dei bevarte? 2. Dersom dei er moderne, korleis klarte dei å koma saman med dei forhistoriske jordmassane? Båe desse er gode spørsmål som det er vanskeleg å gje fullstendige svar på. Det ligg òg eit stadig element av uvisse i dei sidan me må vera sikre på alderen på plantematerialet før me kan velja kva spørsmål me skal svara på. Dømet frå hus 8 på Hove-Sørbø illustrerer ein mogleg måte å tilnærma seg desse spørsmåla på.

\section{Kunnskapsstatus for forkola plantemateriale (makrofossil)}

Forkola plantemateriale har vore utsett for karbonisering, der cellulose og lignin i planterestane raskt har vorte erstatta av karbon. Denne prosessen er ei subfossilisering, men me kallar ofte produktet makrofossil, jamvel om nemninga makrosubfossil er meir korrekt. Det forkola materialet inneheld om lag $60 \%$ reint, elementært karbon. Dette karbonet er vanskeleg tilgjengeleg som næringsstoff for nedbrytarorganismar som sopp og bakteriar, og planterestane vert difor i liten grad utsette for nedbryting (Zohary \& Hopf 2000:4, Robinson et al. 2009:117). Me reknar med at karbonisering har skjedd på éin av to måtar: anten ved varmepåverknad i samband med tørking eller matlaging (Soltvedt 1995:139, Engelmark et al. 1997:100, Viklund 1998:91-92, 166), eller ved ulike typar husbrann (sjå Christensen et al. 2007:67). Felles for desse er at det er menneskeleg aktivitet som har ført til karboniseringa, og makrofossila kan difor knytast direkte til ein aktivitet. Berre i dei tilfella der det er tydeleg at eit heilt hus har brunne ned, kan me vita korleis mesteparten av plantematerialet vart karbonisert (sjå Svendsen 2014:18-27 for utdjuping). I andre tilfelle har karbonisering truleg skjedd gjennom kvardagslege aktivitetar over lengre tid.

Under karboniseringsprosessen må tilgangen på oksygen vera låg, elles vil plantematerialet forbrenna (Viklund 1998:97, Dincauze 2000:334). Temperaturen må opp i $200-250^{\circ} \mathrm{C}$, men stig han over $400-500{ }^{\circ} \mathrm{C}$, vil plantematerialet forbrenna fullstendig (Hillman 1981:139, Viklund 1998:97, Zohary \& Hopf 2000:4, Christensen et al. 2007:88, Sandvik 2008:76). Ved større brannar kjem temperaturen opp i 900-1000 ${ }^{\circ} \mathrm{C}$ (Hansen 2007:33), og i den godt dokumenterte forsøksbrenninga av eit rekonstruert jernalderhus frå Sagnlandet Lejre på Sjælland vart den høgaste temperaturen inne i huset målt til $1126{ }^{\circ} \mathrm{C}$ (Christensen et al. 2007:68). Likevel fanst det framleis karbonisert plantemateriale ved forsøksutgravinga, trass i kva dei høge temperaturane under brannen skulle tilseia (Christensen et al. 2007:94). Dette kan forklarast ved at temperatur og oksygentilgang i ein brann ikkje er jamn (Gustafson 2005:49). Plantemateriale kan i tillegg ha vore verna av behaldarar, eller av andre gjenstandar i huset, og treng difor ikkje ha vore direkte eksponert for flammane. Sjansen for vellukka karbonisering er difor avhengig av fleire faktorar, og me må rekna med at berre ein liten del av det plantematerialet som har vorte utsett for høge temperaturar er bevart som makrofossil.

Det er store skilnader i korleis ulike plantedelar og ulike artar reagerer på varme (Viklund 1998:106, Cappers \& Neef 2012:138). Dette får konsekvensar for kor representative makrofossila me finn, er for det opphavlege utvalet. Til dømes vert oljerike frø ofte heilt øydelagde ved brenning (Viklund 1998:31, 167). Karboniseringsprosessen fører òg til at plantematerialet endrar fasong, avhengig av kva tilstand det var i før karbonisering og av temperatur- og oksygentilhøve under karboniseringa. Frø som vert karboniserte i våt tilstand, vert til dømes deformerte og hòlete makrofossil (Viklund 1998:47). Typisk vert frø kortare og tjukkare når dei vert forkola (Zohary \& Hopf 2000:4), og dei mistar ofte nokre karakteristikum.

Makrofossil er skjøre og spesielt utsette for mekanisk skade. Det har difor vore avgjerande for vidare bevaring at dei har hamna på beskytta plassar. Berre der det er liten slitasje, som inntil veggar, i hjørne, rundt stolpar og i sprekkar i golvet, kan dei ha vore bevarte over tid. Ein slik deponeringsprosess er òg med på å forklara kvifor funnkonsentrasjonen av makrofossil i stolpehòl ofte er relativt høgare enn andre plassar i huset, om me ser vekk frå eventuelle eldstader. Me reknar med at denne typen lågfrekvent deponering over tid er tilfeldig og representerer lokal flora og nyttevekstar som har vorte dyrka lokalt, jamvel om noko òg kan vera importert frå andre plassar (Viklund 1998:18, Dincauze 2000:332, 342). I tilfelle der eit hus har brunne ned, vil det meste av plantefossila stamma frå tidspunktet for brannen (t.d. Grabowski 2012), jamvel om det framleis vil finnast noko «bakgrunnsstøy» frå den føregåande akkumuleringsperioden. Dersom me har grunn til å tru at plantefossila me finn, kan ha vore rituelle nedleggingar eller husoffer (t.d. Regnell 1997), skal me vera varsame med å samanlikna dei med artssamansetjing og mengder frå tilfeldige deponeringar (Viklund 1998:18).

Me kan generelt gå ut ifrå at eit makrofossilmateriale er meir komplekst samansett, di meir kompleks kulturhistoria til ein lokalitet er. Om det ikkje har vore busetnad i området tidlegare, er det lite sannsynleg at det finst forkola plantemateriale i jordmassane frå 
før. Om det derimot har vore tidlegare busetnad eller aktivitet, t.d. svirydjing, kan makrofossil frå desse aktivitetane verta blanda inn i yngre aktivitetslag (van Vilsteren 1984, Ranheden 1996:10, Engelmark et al. 1997:100). Dette er særleg relevant når me arbeider med jordprøver frå stolpehòl sidan desse hòla fyrst er gravne ut og seinare fylte att med blanda massar (sjå t.d. Engelmark 1985:207, Ranheden 1996:11, Gustafson 2005:49). Utskifting av stolpar med gjenbruk av stolpehòl har truleg vore vanleg, og jordmassar vil raskt ha kunna fylt att stolpehòla om stolpane har vorte dregne opp av jorda, slik som tolkinga er av stolpehòl 6 i hus 8 frå Hove-Sørbø. Kontaminering med både eldre og yngre materiale er vanskeleg å unngå så lenge busetnad og aktivitet i eit område held fram, og det er viktig å vera kritisk og ta omsyn til dette i tolkinga av makrofossil frå komplekse bustads- og aktivitetsområde som Hove-Sørbø.

\section{Avsluttande kommentar}

Som me ser av dømet frå hus 8 på Hove-Sørbø, kan planterestar frå jordprøver gje uventa dateringar. Dette illustrerer kor viktig det er at me er sikre på alderen til materialet før me tolkar det inn i ein arkeologisk kontekst. Meir generelt viser materialet frå huset korleis me har lett for å vera noko ukritiske til forkola frø, og at makrofossiltabellar kan gje eit unyansert bilete av kor gamle dei forkola frøa er. Me har òg lett for å generalisera alderen til uforkola frø, men då i retning av å vera kritiske til at materialet kan vera like gamalt som forkola planterestar. Uforkola frø frå jordprøver vert ofte sorterte ut og artsbestemte på same måte som forkola frø, men deretter lagde til sides fordi me er usikre på kva dei representerer. Dette ville òg hendt med alle dei uforkola frøa frå hus 8 om ikkje dette materialet hadde fått særskild merksemd.

Kunnskapsproduksjon knytt til plantemateriale frå arkeologiske kontekstar er ikkje ein beintfram eller enkel prosess. Kunnskapen baserer seg på ei tverrfagleg forståing av tafonomisk, økologisk og arkeologisk tolking, som berre er mogleg med bakgrunn i solid empiri. Det har vore uheldig for metodeutviklinga at plantemateriale til radiokarbondatering i større grad er valt ut med interesse for strukturen det kjem frå, og i mindre grad med interesse for aktivitetane det representerer. Me treng meir tverrfagleg forsking for å få til ei metodeutvikling som på sikt kan utnytta meir av potensialet i plantemateriale frå jordprøver generelt, og ikkje berre i dei spesielle tilfella.

Så lenge det er vanleg å bruka plantemateriale frå jordprøver som proxydata for datering av strukturar, vil det vera ei naturleg prioritering å velja ut det materialet som har størst sannsyn for å vera samtidig med den undersøkte strukturen. Dette er i seg sjølv ikkje eit problem, men det vert fort problematisk om ikkje me tek omsyn til at det daterte materialet ikkje er valt ut tilfeldig, og at det ikkje treng å vera representativt for det resterande plantematerialet i ei prøve. Her vil fleire radiokarbondateringar frå kontekstar med uforkola frø kunna betra føresetnadene våre til å tolka plantemateriale frå jordprøver. For å få til denne kunnskapsutviklinga treng me større medvit om at makrofossilanalyse som metode i arkeologiske kontekstar er eit tverrfagleg prosjekt som føreset arkeologisk vilje for koma vidare.

\section{Takk}

Arkeologisk museum har bidrege med interne forskingsmidlar til to radiokarbondateringar av uforkola frø. Utan desse midlane ville me visst mykje mindre om dei uforkola frøa frå hus 8 på Hove-Sørbø, og tolkingane i denne artikkelen hadde ikkje vore moglege. To anonyme fagfellar har kome med framlegg til viktige betringar som eg har innarbeidd etter beste evne. Eg er òg svært takksam for at Vebjørn Sture, Sofie Scheen Jahnsen, Jonathan Siqveland, Marie Amundsen, Even Bjørdal og Lisbeth Prøsch-Danielsen har lese gjennom manuskriptet og kome med gode innspel.

\section{Summary}

There is a need for more knowledge about macro analysis and interpretation of macro remains from archaeological contexts. This also includes knowledge of taphonomic processes related to the diagenesis, preservation and interpretation of both carbonized and uncarbonized plant remains. Norwegian archaeologists have shown little interest in the methodology of macro analysis, and palaeobotanists have not raised awareness around the subject matter. As a consequence, relevant literature is scarce, and there is little development of macro analysis as a method.

With this as a backdrop, I have addressed the assumptions we make about plant remains, which are not always consistent with reality. In Norway, it is traditionally assumed that all uncarbonized plant remains are modern contamination, unless they have been procured from a sealed, waterlogged or permanently frozen context. Yet this assumption is seldom tested. Uncarbonized remains are therefore rarely considered for radiocarbon dating, as the main aim of acquiring these dates is to establish the age of the archaeological structure from which the soil sample was procured. On the other hand, carbonized plant remains, commonly referred to as macrofossils, are too often assumed to originate from activities associated with a given structure. These assumptions are more readily tested through radiocarbon dating, but there still are some issues related to how the results are presented 
in various publications. Often, macrofossil dates will be presented in association with an archaeological structure, and not together with the rest of the macrofossil assemblage. This leads to an apparent detachment of the macrofossils and their dates, making the unfortunate impression that all macrofossils are simultaneous with the structure, regardless of the actual dates and their deviations.

As a case study, carbonized and uncarbonized plant remains from a house that dates to the transition between the Pre-Roman Iron Age and the Roman Iron Age at HoveSørbø in Southwestern Norway are investigated. The house is typical for the period, and all soil samples for macro analysis have been collected from five pairs of roof supporting postholes. As a precaution of contamination with modern seeds, samples have been collected from the mid- and bottom layers of the postholes, leaving the uppermost soil layer intact. Contrary to what we expected, radiocarbon dates from two carbonized cereal grains of barley (Hordeum) and oat (Avena) showed that these were from the Late Neolithic period and modern times, respectively. However, dates from two charcoal samples of deciduous wood were consistent with the typological dating of the house. Apparently, preservation conditions at Hove-Sørbø have been poor with no sealed contexts. Two samples with a total of 1062 uncarbonized seeds from the arable weeds fat-hen (Chenopodium album) and corn spurrey (Spergula arvensis) were therefore radiocarbon dated to verify that the uncarbonized seeds were in fact modern. The results, however, showed that the seeds were 2000 years old, and probably deposited while the house was still in use.

This example illustrates that there can be an unused potential to uncarbonized seeds that would otherwise have been discarded as contamination. The fact that prehistoric uncarbonized seed were present, suggests that they may have been sealed soon after deposition, probably in the posthole itself. It is possible that this occurred during deconstruction of the house, when the postholes could shortly have been refilled with soil and clay. There are large finds of both fat-hen (Chenopodium album) and corn spurrey (Spergula arvensis) from Jutland, Denmark, meant for human consumption. However, this is probably not the case with the seeds from Hove-Sørbø as concentrations should have been much higher to support this interpretation. It is more likely that these pastoral weeds have been introduced to the site as a by-product of crop processing, most likely residues from fine sieving of cereal grains around the entrance area of the house. The hard and resistant seed coatings of fat-hen (Chenopodium album) and corn spurrey (Spergula arvensis) have ensured that they are the only species which survives in the by-product assemblages preserved today.

In order to be able to discover and interpret such finds, we must pay more attention to macro sample methodology and knowledge production. By making generalised assumptions about the age of plant materials from soil samples, we end up being both insufficiently critical of the carbonized remains, and too critical of the uncarbonized remains. As this is an inherently interdisciplinary project, the involvement of palaeobotanists as well as archaeologists is a prerequisite for further data collection, methodology discussions and knowledge production.

\section{Referansar}

Amundsen, M. \& Fredriksen, P.D. 2014. Når stedsbånd veves og løses opp. En sosial kronologi for bosetningen av Kalvebeitet i indre Sogn i yngre romertid og folkevandringstid. Viking LXXVII, 79-104.

Bakkevig, S., Griffin, K., Prøsch-Danielsen, L., Sandvik, P.U., Simonsen, A., Soltvedt, E.-C., \& Virnovskaia, T. 2002. Archaeobotany in Norway: Investigations and methodological advances at the Museum of Archaeology, Stavanger. I Viklund, K. (red.). Nordic archaeobotany: NAG 2000 in Umeå, s. 23-48. Archaeology and Environment 15. Department of Archaeology and Sami studies, Universitetet i Umeå, Umeå.

Behre, K.-E. 1981. The interpretation of anthropogenic indicators in pollen diagrams. Pollen et Spores XXIII, 2, $225-245$.

Bertsch, K. 1941. Früchte und Samen. Ein Bestimmungsbuch zur Pflanzenkunde der vorgeschichtlichen Zeit. Verlag Ferdinand Enke, Stuttgart.

Bjørdal, E. 2014. Gardar og graver frå steinalder til mellomalder på Hove og Sørbø i Sandnes. Frá haug ok heiðni 3, $10-19$.

Bjørdal, E. 2017, in press. Oppdragsrapport frå dei arkeologiske undersøkingane på Hove og Sørbø i Sandnes k. i 2011-12. Hus og gard frå bronsealder til mellomalder.

Brandt, I. 1951. Planterester i et moselig fra Borremose. Aarbøger for nordisk oldkyndighed og historie 1950, 342-349.

Børsheim, R.L. \& Soltvedt, E.-C. 2002. Gausel - utgravingene 1997-2000. AmS-Varia 39, Stavanger.

Cappers, R.T.J., Bekker, R.M. \& Jans, J.E.A. 2006. Digitale Zadenatlas van Nederland. Barkhuis Publishing \& Groningen University Library, Groningen.

Cappers, R.T.J. \& Neef, R. 2012. Handbook of plant palaeoecology. Barkhuis, Groningen.

Christensen, L.B., Jensen, S.E., Johansen, A.L.L., Johansen, P.R. \& Lerager, S. 2007. House 1 - experimental fire and archaeological excavation. I Rasmussen, M. (red.). Iron age houses in flames: testing house reconstructions at Lejre, s. 42-133. Studies in Technology and Culture. HistoricalArchaeological Experimental Centre, Lejre.

Davis, M.B. 2000. Palynology after Y2K - Understanding the Source Area of Pollen in Sediments. Annual Review of Earth and Planetary Sciences 28, 1-18.

Dincauze, D.F. 2000. Environmental archaeology: principles and practice. Cambridge University Press, Cambridge.

Eilertsen, K.S. 2011. Rapport fra kulturhistorisk registrering. Sømme Gnr. 15, Bnr. 5, 12, 25, 32, 50, 166, 440. Kulturseksjonen, Regionalutviklingsavdelingen, Rogaland fylkeskommune.

Engelmark, R. 1985. Carbonized seeds in postholes - a reflection of human activity. ISKOS 5, 205-210.

Engelmark, R. 1997. Replik på «Metodutveckling eller metoavveckling?». Kulturminnevård 4, 101.

Engelmark, R., Gustafsson, S. \& Viklund, K. 1997. Metodutveckling eller metodavveckling? Några synspunkter på stolphålsarkeobotanik i Mälardalen. Kulturmiljövård 4, 99-100.

Fægri, K. 1970. Norges planter. Blomster og trcer i naturen. Med et utvalg fra våre nabolands flora. Band 1. Cappelen, Oslo.

Fægri, K. \& Iversen, J. 1989. Textbook of Pollen Analysis. Wiley \& Sons, Chichester. 
Grabowski, R. 2012. Archaeobotanical analysis of plant macrofossil material from VKH 7087, Kristinebjerg Øst etape 4, Velja Amt, East Jutland, Denmark. Rapportnr. 2012-027. Department of Historical, Philosophical and Religious Studies, Universitetet i Umeå.

Gustafson, L. 2005. Hvor gammelt er huset? Om datering av langhusene på Veien, Ringerike. I Høgestøl, M., Selsing, L., Løken, T., Nærøy, A.J. \& Prøsch-Danielsen, L. (red.). Konstruksjonsspor og byggeskikk. Maskinell flateavdekking - metodikk, tolking og forvaltning, s. 45-56. AmS-Varia 43, Stavanger.

Hansen, H.-O. 2007. The fire we started. I Rasmussen, M. (red.). Iron age houses in flames: testing house reconstructions at Lejre, s. 32-41. Studies in Technology and Culture. Historical-Archaeological Experimental Centre, Lejre.

Hardt, N. 2003. Jernalderens og vikingetidens landbrug. I Ethelberg, P., Hardt, N., Poulsen, B. \& Sørensen, A.B. (red.). Det sønderjyske landbrugs historie: jernalder, vikingetid og middelalder, s. 17-122. Haderslev Museum og Historisk Samfund for Sønderjylland, Haderslev.

Harild, J.A., Robinson, D.E. \& Hudlebusch, J. 2007. I Asingh, P. \& Lynnerup, N. (red.). Grauballe Man. An Iron Age Bog Body Revisited, s. 154-187. Jysk Arkæologisk Selskab, Mosgaard.

Hebsgaard, M.B., Gilbert, M.T.P., Arneborg, J., Heyn, P., Allentoft, M.E., Bunce, M., Munch, K., Schweger, C. \& Willerslev, E. 2009. 'The Farm Beneath the Sand' - an archaeological case study on ancient 'dirt' DNA. Antiquity 83, 320, 430-444.

Helbæk, H. 1951a. Ukrudtsfrø som næringsmiddel i førromersk Jernalder. Kuml 1951, 65-74.

Helbæk, H. 1951b. Tollundmandens sidste maaltid. Et botanisk bidrag til belysning af oldtidens kost. Aarbøger for nordisk oldkyndighed og historie 1950, 311-341.

Helbæk, H. 1959. Grauballemandens sidste måltid. Kuml 1958, 83-116.

Henriksen, P.S. \& Robinson, D.E. 1996. Early Iron Age agriculture: archaeobotanical evidence from an underground granary at Overbygård in northern Jutland, Denmark. Vegetation History and Archaeobotany 5, 1-11.

Hillman, G. 1981. I Mercer, R. (red.). Farming Practice in British Prehistory. Reconstructing Crop Husbandry Practices from Charred Remains of Crops, s. 123-162. Edinburgh University Press, Edinburgh.

Hillman, G. 1984. I van Zeist, W. \& Casparie, W.A. (red.). Plants and Ancient Man. Studies in Palaeoethnobotany. Interpretation of archaeological plant remains: The application of ethnographic models from Turkey, s. 1-41. Balkema, Rotterdam.

Hjelle, K.L. \& Sugita, S. 2012. Estimating pollen productivity and relevant source area of pollen using lake sediments in Norway: How does lake size variation affect the estimates? The Holocene 22, 3, 313-324.

Holmboe, J. 1905. Studier over norske planters historie. III. En samling kulturplanter og ugræs fra vikingetiden. $\mathrm{Nyt}$ magazin for naturvidenskaberne 44, 61-74.

Holmboe, J. 1917. Oseberghaugens torv. I Brøgger, A.W., Falk, H.J. \& Shetelig, H. (red.). Osebergfundet, s. 201-208. Den norske stat, Oslo.

Jackson, S.T. \& Lyford, M.E. 1999. Pollen Dispersal Models in Quaternary Plant Ecology: Assumptions, Parameters, and Prescriptions. The Botanical Review 65, 1, 39-75.
Katz, N.Y., Katz, S.V. \& Kipiani, M.G. 1965. Atlas and keys of fruits and seeds occuring in the Quaternary deposits of the USSR. Nauka, Moskva.

Korsmo, E., Vidme, T. \& Fykse, H. 1981. Korsmos ugrasplansjer. Norsk landbruk/Landbruksforlaget, Oslo.

Lid, J. \& Lid, D.T. 2005. Norsk flora. Samlaget, Oslo.

Løken, T. 1998. Hustyper og sosialstruktur gjennom bronsealder på Forsandmoen, Rogaland, Sørvest-Norge. I Løken, T. (red.). Bronsealder $i$ Norden - regioner og interaksjon. Foredrag ved det 7. Nordiske bronsealdersymposium $i$ Rogaland 31. august-3. september 1995, s. 107-130. AmSVaria 33, Stavanger.

Neef, R., Cappers, R.T.J. \& Bekker, R.M. 2012. Digital atlas of economic plants in archaeology. Barkhuis Publishing \& Groningen University Library, Groningen.

Nesbitt, M. 2006. Identification guide for Near Eastern grass seeds. Institute of archaeology, University College London, London.

Nesje, A., Pilø, L.H., Finstad, E. Solli, B., Wangen, V., Ødegård, R.S., Isaksen, K., Støren, E.N., Bakke, D.I. \& Andreassen, L.M. 2012. The climatic significance of artefacts related to prehistoric reindeer hunting exposed at melting ice patches in southern Norway. The Holocene 22, 4, 485-496.

O'Connor, T. \& Evans, J.G. 2005. Environmental archaeology: principles and methods. Sutton Publishing, Gloucestershire.

Prentice, C. 1985. Pollen Representation, Source Area, and Basin Size: Toward a Unified Theory of Pollen Analysis. Quaternary Research 23, 76-86.

Prescott, C. 2012. Et essay om naturvitenskapene og arkeologien. Nicolay 118, 5-10.

Preston, C.D., Pearman, D.A. \& Dines, T.D. (red.) 2002. New Atlas of the British and Irish Flora. Oxford University Press, New York.

Prøsch-Danielsen, L. 1993. Prehistoric agriculture revealed by pollen analysis, plough-marks and sediment studies at Sola, south-western Norway. Vegetation History and Archaeobotany 2, 4, 233-244.

Prøsch-Danielsen, L.2005. Historisk riss av utvikling og integrering av arkeologiske og naturvitenskapelige metoder. Eksempler fra Forsand og Rogaland forøvrig. I Høgestøl, M., Selsing, L., Løken, T., Nærøy, A.J. \& Prøsch-Danielsen, L. (red.). Konstruksjonsspor og byggeskikk. Maskinell flateavdekking - metodikk, tolking og forvaltning, s. 15-27. AmS-Varia 43, Stavanger.

Ranheden, H. 1996. Makrofossilanalys - Funktionsbestämning av hus. En källkritisk studie. I Ranheden, H., Hyenstrand, E., Jakobsson, M., Rönnby, J. \& Nilsson, A. (red.). Metodstudier E tolkningsmöjligheter, s. 9-28. Riksantikvarieämbetet, arkeologiska undersökningar 20, Stockholm.

Regnell, M. 1997. Växtoffer. En förbisedd fyndkategori i huslämningar. I Karsten, P. (red.). Carpe Scaniam: Axplock ur Skånes förflutna, s. 103-110. Riksantikvarieämbetet, arkeologiska undersökningar 22, Stockholm.

Renfrew, C. \& Bahn, P. 1991. Archaeology. Theories, Methods, and Practice. Thames and Hudson, London.

Robinson, D.E., Mikkelsen, P.H. \& Malmros, C. 2009. Agerbrug, driftsformer og planteressourcer i jernalder og vikingetid (500 f.Kr.-1100 e.Kr.). I Odgaard, B. \& Rømer, J.R. (red.). Danske landbrugslandskaber gennem 2000 år: fra digevoldinger til støtteordninger, s. 117-142. Aarhus Universitetsforlag, Århus. 
Sandvik, P.U. 2008. Naturvitskapleg syntese. Band 5. I Bårdseth, G.A. (red.). E6-prosjektet Østfold. Evaluering - resultat, s. 61-78. Varia 69. Kulturhistorisk museum, Fornminneseksjonen, Oslo.

Seppä, H. \& Bennett, K.D. 2003. Quaternary pollen analysis: recent progress in palaeoecology and palaeoclimatology. Progress in Physical Geography 27, 4, 548-579.

Solem, T. 1999. Makrofossilundersøkelse. Kvenild, Trondheim, Sør-Trøndelag. Vitenskapsmuseet NTNU, Trondheim.

Solem, T. 2004. Makrofossilundersøkelse. Husby søndre, Stjørdal, Nord-Trøndelag. Seksjon for naturhistorie, Vitenskapsmuseet NTNU, Trondheim.

Soltvedt, E.-C. 1995. Makrofossiler (forkullete frø og frukter). I Høgestøl, M. (red.). Arkeologiske undersøkelser $i$ Rennesøy kommune, Rogaland, Sørvest-Norge, s. 110-112. AmS-Varia 23, Stavanger.

Stuiver, M. \& Reimer, P.J. 1993. Extended ${ }^{14} \mathrm{C}$ Data Base and Revised CALIB 3.0 ${ }^{14} \mathrm{C}$ Age Calibration Program. Radiocarbon 35, 215-230. @1986-2015 Calib Radiocarbon Calibration Program. Calib Rev 7.1.

Sugita, S. 1993. A Model of Pollen Source Area for an Entire Lake Surface. Quaternary Research 39, 239-244.
Sugita, S. 1994. Pollen representation of vegetation in Quaternary sediments: Theory and method in patchy vegetation. Journal of Ecology 82, 881-897.

Svendsen, M. 2014. Brent og ubrent plantemateriale. Undersøking av to treskipa hus frå førromersk jernalder på prosjektet Hove-Sørbø i Sandnes. Upublisert masteravhandling i biologi, Universitetet i Bergen.

van Vilsteren, V.T. 1984. The medieval village of Dommelen: A case study for the interpretation of charred seeds from postholes. I van Zeist, W. \& Casparie, W.A. (red.). Plants and ancient man: Studies in palaeoethnobotany, s. 227-235. Balkema, Rotterdam.

Viklund, K. 1998. Cereals, weeds and crop processing in Iron Age Sweden: methodological and interpretive aspects of archaeobotanical evidence. Umeå Universitet, Umeå.

Wilkinson, K. \& Stevens, C. 2003. Environmental archaeology: approaches, techniques and applications. Tempus, Stroud.

Zohary, D. \& Hopf, M. 2000. Domestication of plants in the old world: the origin and spread of cultivated plants in West Asia, Europe and the Nile Valley. Oxford University Press, Oxford.

Ødum, S. 1965. Germination of Ancient Seeds. Dansk Botanisk Arkiv 24, 2. 